\title{
Genetic variation and heterotic effects for seed oil, seed protein and yield attributing traits in upland cotton (Gossypium hirsutum L.)
}

\author{
Kaliyaperumal Ashokkumar* and Rajasekaran Ravikesavan
}

Centre for Plant Breeding and Genetics, Tamil Nadu Agricultural University, Coimbatore - 641 003, Tamil Nadu, India.

Accepted 8 August, 2013

\begin{abstract}
An investigation was carried out to assess the expression of per se performance and heterotic effect for seed oil, seed protein besides various yield attributing characters studied from 28 hybrids involving four adapted varieties as lines and the seven testers in line $x$ tester analysis. A wide range of variability was observed for seed oil content in the parents and their 28 hybrids. The seed oil content in parents ranged from 17.0 to $22.1 \%$, and hybrids varied from 17.7 to $22.9 \%$. The hybrid, MCU 12 x SOCC 11 exhibited significant positive heterotic effect and per se performance for boll weight. The hybrid MCU 5 x SOCC 17 had high per se performance and positive significant heterotic effect for seed protein with seed cotton yield. Two hybrids showed high heterotic effect and per se performance for seed protein content. The hybrid MCU 12 x SOCC 17 exhibited higher per se performance and heterotic effect for seed cotton yield along with seed oil content and MCU $5 \times$ SOCC 17 recorded more seed protein combined with seed cotton yield. Four hybrids revealed greater per se performance and positive heterosis for seed oil content. Of these, Surabhi x TCH 1646 exhibiting highest per se performance, heterotic effect was found to be best for directional selection.
\end{abstract}

Key words: Cotton, heterosis, seed oil, seed protein, yield.

\section{INTRODUCTION}

Cotton crop is mainly cultivated for fibre. The cotton seed, a by-product, is an important source of edible oil. Cotton seed is the second largest source of vegetable oil in the world. In India, secondary source of edible oil production is 19.90 lakh tons. Cotton seed oil is generally considered as healthy vegetable oil. It is cholesterol free and hence termed as "Heart oil". After extraction of oil, the cotton seed meal is a protein rich by product and assumes great importance in feed and fermentation industries. Therefore, cotton seed has an important contribution in helping to feed the world in the future.

The genetic improvement of a new variety with high yield and seed quality parameters is the unique target of all cotton breeders. Industrial demand of cotton with superior fibre trait is also source of guide line for cotton breeders. The success of transgressive segregation depends on the identification of genotypes with the ability to transmit high production potential into specific genotypic combinations. Heterosis is a performance of $F_{1} / F_{2}$ genotypic combinations and is useful in determining the most appropriate parents for specific traits (Khan et al., 2010). Development of hybrids as a commercial variety is getting importance. Heterosis has substantially remained as one of the significant developments in cotton breeding programs (Baloch et al., 2003; Ansari et al., 2004; Ansari et al., 2005; Memon et al., 2005; Ansari et al., 2006).

The yield increase through intra- and inter-specific heterosis over the better parent or best commercial cultivar 
Table 1. List of parental genotypes used for genetic studies in upland cotton.

\begin{tabular}{lll}
\hline S/N & Parent & \multicolumn{1}{c}{ Source } \\
\hline Lines & MCU 5 & Department of Cotton, TNAU, Coimbatore-3, India. \\
1 & MCU 12 & Department of Cotton, TNAU, Coimbatore-3, India. \\
2 & SURABHI & CICR, Regional station, Coimbatore-3, India. \\
3 & SVPR 2 & Department of Cotton, TNAU, Coimbatore-3, India. \\
4 & & \\
Testers & & \\
1 & F 776 & CICR, Regional station, Coimbatore-3, India \\
2 & F 1861 & CICR, Regional station, Coimbatore-3, India \\
3 & SOCC 11 & CICR, Regional station, Coimbatore-3, India \\
4 & SOCC 17 & Department of Cotton, TNAU, Coimbatore-3, India. \\
5 & TCH 1641 & Department of Cotton, TNAU, Coimbatore-3, India. \\
6 & TCH 1644 & Department of Cotton, TNAU, Coimbatore-3, India. \\
7 & TCH 1646 &
\end{tabular}

CICR, Central Institute for Cotton Research, TNAU, Tamil Nadu Agricultural University.

(useful heterosis) has been documented (Galanopoulou and Roupakias, 1999; Wei et al., 2002; Yuan et al., 2002; Zhang et al., 2002; Khan et al. 2007a). The oil content increase through intra-hirsutum hybrids over mid parent and better parent were documented (Kowsalya et al., 1999; Ganapathy and Nadarajan, 2008).

Several studies have been reported on seeds traits, but little work has been reported on the genetics and heterosis of cottonseed oil percentage in cotton breeding. A few reports in the literature (Kohel, 1980; Dani and Kohel, 1989; Dani, 1991; Khan et al., 2007b; Ganapathy and Nadarajan, 2008; Sharma et al., 2009; Khan et al., 2010) have determined that cotton genotypes differ in oil percentage. The estimates of per se performance and heterosis provided useful information with regard to the possibilities and extent of improvement in the characters of breeding material through selection. Any breeding programme has to consider the improvement in quality, especially in crop like cotton. Seed quality generally increases with high level of seed oil but declines with the increase of seed cotton yield. For a simultaneous selection of both quality and yield, knowledge of inter relationship between the components of quality and those of yield is a pre-requisite. In cotton, heterosis studies for seed cotton yield and other fiber properties are many. But to know the nature and extent of heterosis for oil content with seed cotton yield and other traits are limited.

Therefore, the present study objective was to estimate genetic variation for mean performance of parents and their hybrids and to estimate the effects of heterosis in $F_{1}$ cross combinations, to obtain information heterotic potential as to develop hybrid with improved yield along with high seed oil content through line $x$ tester $(L \times T)$ analysis.

\section{MATERIALS AND METHODS}

\section{Genetic material}

A field experiment was conducted to evaluate the growth, yield and fibre quality traits performance of four commercially cultivated varieties of cotton (Gossypium hirsutum L.) as viz., MCU 5, MCU 12, Surabhi and SVPR 2 and seven G. hirsutum genetic accessions as viz., F 776, F 1861, SOCC 11, SOCC 17, TCH 1641, TCH 1644 and TCH 1646 (Table 1). The commercial cultivars were cultivated in southern states of India and genetic accessions were collected from the Central Institute of Cotton Research, Coimbatore, Tamil Nadu, India.

\section{Experimental design and field procedures}

The cotton cultivars and accessions were evaluated in randomized block design (RBD) with three replications at Cotton Breeding Station, Tamil Nadu Agricultural University, Coimbatore, and Tamil $\mathrm{Nadu}$ in India. Each genotype was grown in a $4.5 \mathrm{~m}$ length row adopting a spacing of $75 \mathrm{~cm}$ between rows and $30 \mathrm{~cm}$ between the plants, so as to have 15 plants per row.

\section{Sampling, traits measurements and methods}

Data were recorded on five randomly selected plants per replication for all the 11 characters viz., Plant height $(\mathrm{cm})$, number of sympodia per plant, number of bolls per plant, boll weight per plant $(\mathrm{g})$, number of seeds per boll, seed cotton yield per plant $(\mathrm{g})$, ginning outturn $(\%)$, lint index $(\mathrm{g})$, seed index $(\mathrm{g})$, seed oil content $(\%)$ and seed protein content $(\%)$. The line $x$ tester analysis of heterosis was performed as suggested by Kempthorne, (1957). Heterosis was calculated in terms of percent increase $(+)$ or decrease $(-)$ of the $F_{1}$ hybrids against its mid parent, and better parent value as suggested by Fehr (1987).

\section{Biochemical analysis}

The seed oil content of parents and their $F_{1}$ hybrids was estimated 
Table 2. Analysis of variance for seed oil, seed protein and yield traits from $L X T$ analysis.

\begin{tabular}{|c|c|c|c|c|c|c|c|c|c|c|c|c|}
\hline \multirow[b]{2}{*}{$\begin{array}{l}\text { Source of } \\
\text { variation }\end{array}$} & \multicolumn{12}{|c|}{ Mean square } \\
\hline & df & $\begin{array}{c}\text { Plant } \\
\text { height } \\
(\mathbf{c m})\end{array}$ & $\begin{array}{c}\text { Number of } \\
\text { sympodia/ } \\
\text { plant }\end{array}$ & $\begin{array}{l}\text { Number } \\
\text { of bolls }\end{array}$ & $\begin{array}{c}\text { Boll } \\
\text { weight (g) }\end{array}$ & $\begin{array}{l}\text { Number of } \\
\text { seeds/bolls }\end{array}$ & $\begin{array}{c}\text { Ginning } \\
\text { outturn (\%) }\end{array}$ & $\begin{array}{c}\text { Lint } \\
\text { index } \\
(\mathrm{g})\end{array}$ & $\begin{array}{c}\text { Seed } \\
\text { index } \\
(\mathrm{g})\end{array}$ & $\begin{array}{c}\text { Seed cotton } \\
\text { yield } \\
\text { (g/plant) }\end{array}$ & $\begin{array}{l}\text { Seed oil } \\
(\%)\end{array}$ & $\begin{array}{c}\text { Seed } \\
\text { protein } \\
(\%) \\
\end{array}$ \\
\hline Parents & 10 & $2.73^{* *}$ & $3.91^{* *}$ & $2.95^{\star *}$ & $2.38^{\star}$ & $4.13^{\star *}$ & $3.40^{* *}$ & $5.28^{\star *}$ & $2.41^{\star}$ & $12.22^{\star *}$ & $15.61^{\star \star}$ & $25.47^{\star \star}$ \\
\hline Hybrids & 27 & $16.69^{\star \star}$ & $1.73^{\star}$ & $4.92^{\star *}$ & $1.72^{\star}$ & $2.54^{\star *}$ & $5.98^{\star *}$ & $2.38^{\star \star}$ & $2.61^{* *}$ & $23.53^{\star \star}$ & $24.54^{\star \star}$ & $102.49^{\star *}$ \\
\hline Parents vs hybrids & 1 & $222.76^{\star *}$ & $6.61^{*}$ & $20.39^{* *}$ & $17.71^{\star *}$ & $33.20^{* *}$ & $35.15^{\star *}$ & 2.36 & 2.88 & $523.99^{* *}$ & 1.70 & $48.48^{\star *}$ \\
\hline Replication & 2 & 0.82 & 2.26 & 1.67 & 0.66 & 0.35 & 0.01 & 1.79 & 1.26 & 3.35 & 1.98 & 13.84 \\
\hline Lines & 3 & $3.41^{*}$ & $4.29^{* \star}$ & $6.17^{\star *}$ & 1.40 & 0.59 & 0.82 & 0.56 & 2.24 & $12.47^{\star *}$ & 1.12 & $14.19^{* *}$ \\
\hline Tester & 6 & 0.41 & 0.55 & 0.91 & 1.88 & 1.39 & 1.91 & 1.73 & 1.40 & $3.23^{\star *}$ & 0.26 & 1.19 \\
\hline line $x$ tester & 18 & $12.91^{* *}$ & $2.08^{*}$ & $4.35^{\star \star}$ & $2.01^{*}$ & $3.06^{\star \star}$ & $4.23^{*}$ & $2.25^{\star}$ & $1.92^{*}$ & $10.15^{\star *}$ & $30.37^{\star \star}$ & $75.20^{\star *}$ \\
\hline Error & 54 & 7.42 & 3.39 & 2.59 & 0.08 & 1.45 & 2.23 & 0.28 & 1.39 & 9.4 & 0.27 & 0.46 \\
\hline
\end{tabular}

*, Significant at $5 \%$ level; **, significant at $1 \%$ level.

by nuclear magnetic resonance analyses (NMR) (Oxford 4000 NMR auto Analyser) using $10 \mathrm{~g}$ delinted seed for each sample. Before NMR analysis, the delinted seeds were dried at $38^{\circ} \mathrm{C}$ for $24 \mathrm{~h}$. Seed protein content was estimated through total nitrogen content using Microkjeldhal method (Humphries, 1956), and seed protein content was calculated by multiplying the nitrogen content with a factor 6.25 and the result was expressed as percentage.

\section{RESULTS AND DISCUSSION}

Evaluation of mean performance and heterotic effect is essential to know whether new cross combinations are suitable for direct exploitation or can be used to isolate useful and transgressive segregants from subsequent generation to develop a variety. The utilization of hybrids directly for commercial production mainly depends upon the nature and extent of heterosis. Increasing $F_{1}$ hybrid value over the better parent value is more relevant for exploitation of heterosis for commercial purpose (Williams and Gilbert, 1960). The expression of heterosis was worked out for all the characters over mid parent, and better parent was estimated in the entire cross combinations under this study.

\section{Analysis of variance}

The analysis of variance showed that line was significant for the characters viz., plant height, number of sympodia, number of bolls, seed cotton yield, and seed protein. The testers varied significantly for the seed cotton yield. In case of the line $\mathrm{x}$ tester component, significant variation was observed for all the characters (Table 2). Between the parents and hybrids, significant variation was observed for all the characters. In addition, the parents versus hybrids showed significant varia- tion for all the characters except lint index, seed index, and seed oil.

\section{Genetic variability in $F_{1}$ hybrids and their parents}

Significant variation was found for each trait in all the genotypes. The mean expression of the 11 characters was recorded on the 11 genotypes. All the 11 cotton genotypes (four lines and seven testers) differ significantly for plant height. The maximum plant height $(122.5 \mathrm{~cm})$ was observed in TCH 1646, and the lowest $(112.6 \mathrm{~cm})$ was observed in SOCC 17. Among the 28 hybrids, the weakest value of $120.1 \mathrm{~cm}$ and highest value of $143.1 \mathrm{~cm}$ were recorded in MCU $5 \times \mathrm{F} 776$ and MCU $5 \times \mathrm{TCH} 1641$, respectively. Differences observed for plant height among cotton cultivars can be attributed to variation in genetic makeup of 
Table 3. Ranges for mean expression of parents in different characters.

\begin{tabular}{lcccll}
\hline \multirow{2}{*}{ Character } & Minimum value & \multirow{2}{*}{ Maximum value } & \multirow{2}{*}{ Mean } & \multicolumn{2}{c}{ Parent recording } \\
\cline { 6 - 6 } & & & & Lowest & Highest \\
\hline Plant height (cm) & 113.6 & 122.5 & 120.71 & SOCC 17 & TCH 1641 \\
No. of sympodia/plant & 20.00 & 29.00 & 22.32 & TCH 1641 & F 776 \\
Number of bolls/plant & 20.10 & 26.47 & 23.60 & F 776 & Surabhi \\
Boll weight/boll (g) & 3.36 & 4.19 & 3.92 & TCH 1644 & MCU 5 \\
Number of seeds / boll & 26.70 & 32.00 & 29.70 & TCH 1644 & TCH 1641 \\
Seed cotton yield (g/plant) & 59.40 & 95.33 & 83.43 & TCH 1644 & MCU 12 \\
Ginning outturn (\%) & 31.68 & 36.24 & 34.0 & SOCC 17 & Surabhi \\
Lint index (g) & 3.96 & 6.12 & 5.01 & SOCC 11 & SVPR 2 \\
Seed index (g) & 8.05 & 11.11 & 9.25 & F 1861 & F 776 \\
Seed oil (\%) & 17.74 & 22.07 & 19.94 & F 1861 & TCH1644 \\
Seed protein (\%) & 19.39 & 27.69 & 23.67 & Surabhi & MCU 5 \\
\hline
\end{tabular}

crop plants. These results are supported by the findings of Anwar et al. (2002) and Copur (2006) who also noted significant differences among cultivars for plant height. In parents, highest number of sympodia per plant and lowest number of sympodia per plant were produced by TCH 1614 and F776, respectively (Table 3). In hybrids, the weakest value of 21.7 (SVPR $2 \times \mathrm{TCH}$ 1641) and the greatest value of 27.2 (Surabhi $x$ F 776) were recorded with a mean value of 25.0. The difference to the number of sympodial branches per plant can be attributed to differences in genetic makeup of the cultivars.

There was significant difference between the parents in case of the number of bolls per plant. Significant and maximum number of bolls per plant was observed in cultivar SURABHI (26.5). The minimum number of bolls per plant was found in accession F776 (20.1). The hybrids displayed a variation from 21.40 bolls in SVPR 2 $x$ SOCC 11 to 32.4 bolls in MCU $12 \times \mathrm{F} 1861$ for the number of bolls per plant with a mean value of 25.4 bolls. The result indicating the importance of hybrid MCU $12 \mathrm{x}$ $F 1861$ offering the scope of selection and can be utilized for the improvement of number of bolls per plant which will directly influence the seed cotton yield. In addition, the present results have been further supported by Soomro (2000), Baloch (2002), Chandio et al. (2002), Basbag and Gencer (2004) and Soomro et al., (2008).

Boll weight is directly related to the seed cotton yield of cotton. An evaluation of data indicated that greatest boll weight was recorded in cultivar MCU12 (4.2 g), and it was on par with cultivar MCU5 $(4.14 \mathrm{~g})$ and SVPR 2 $(4.12 \mathrm{~g})$ the lowest boll weight was recorded in accession TCH1644 (3.36 g). Significant differences among parents for average boll weight also were reported by Hofs et al. (2006). Boll weight variation among the hybrids ranged from $3.8 \mathrm{~g}$ in Surabhi $x$ SOCC 11 to $4.4 \mathrm{~g}$ in MCU $12 \mathrm{x}$ SOCC 11, and the mean value was $4.2 \mathrm{~g}$. Boll weight was positively associated with seed cotton yield as reported (Rauf et al., 2004; Gite et al., 2006; Preetha and Raveendran, 2007). There was significant difference among the parents and hybrids in case of the number of seeds per boll. Maximum and minimum number of seeds per boll observed was 32.0 and 26.7, respectively. The average number of seeds per boll for all the genotypes was 29.7 (Table 3). The hybrids displayed a variation from 29.6 in Surabhi $\times$ TCH 1641 and SVPR $2 \times \mathrm{TCH}$ 1646 to 34.9 in Surabhi x SOCC 11.

All the parents and hybrids had wide variation for seed cotton yield per plant. The cultivar MCU 12 produced significantly higher seed cotton yield $(95.3 \mathrm{gm} /$ plant) and lowest seed cotton yield was registered by the accession $\mathrm{TCH} 1644$ (59.5 gm/plant). The mean yield of all the genotypes was $83.4 \mathrm{~g} /$ plant. Lowest yield of $87.7 \mathrm{~g}$ was recorded by a Surabhi $\times$ TCH 1646 and highest yield of $145.4 \mathrm{~g}$ was recorded by MCU $12 \times \mathrm{F} \mathrm{1861}$, and the mean value of hybrids was $106.96 \mathrm{~g}$. The maximum seed cotton yield with MCU $12 \times \mathrm{F} 1861$ can be attributed to the maximum number of sympodia per plant, number of bolls, boll weight, ginning outturn, lint index and seed index. Similar findings for seed cotton yield have also been reported by early workers (Baloch, 2004; Soomro et al., 2008). Hence, suggesting the prompt selection of the hybrid MCU 12 x F 1861 for increasing seed cotton yield per plant and suggesting the utilization of this hybrid for evolving new high yielding genotypes of cotton.

The highest value of ginning out turn was obtained in case of cultivar SURABHI (36.2\%), but it was on par with cultivars SVPR 2 (35.8\%) and MCU12 (35.4\%). Among the hybrids, MCU $5 \times \mathrm{TCH} 1646$ recorded minimum $(30.0 \%)$ ginning outturn while SVPR $2 \times$ SOCC 11 registered maximum ginning outturn of $39.9 \%$. The mean expression for ginning out turn in hybrids was $35.6 \%$. These results were supported by those of Ehsan et al. (2008). There were significant differences in all the hybrids in the case of lint index (g) and seed index (g) (Table 4).

A wide range of variability was observed for seed oil content in the parents and their 28 hybrids. The oil content in parents ranged from 17.7 (\%) to 22.1 in $\mathrm{F} 1861$ 
Table 4. Mean performance and expression of heterosis in hybrids (\%) for yield attributing traits.

\begin{tabular}{|c|c|c|c|c|c|c|c|c|c|c|c|c|}
\hline \multirow{2}{*}{ Hybrid } & \multicolumn{3}{|c|}{ Plant height (cm) } & \multicolumn{3}{|c|}{ Number of sympodia / plant } & \multicolumn{3}{|c|}{ Number of bolls/plant } & \multicolumn{3}{|c|}{ Boll weight/boll (g) } \\
\hline & mean & di & dii & Mean & di & dii & Mean & di & dii & Mean & di & dii \\
\hline MCU 5 x F 776 & 120.07 & -1.14 & -1.21 & 4.11 & 9.75 & -1.60 & 24.90 & $12.75^{*}$ & 3.46 & 4.11 & 0.24 & -1.83 \\
\hline MCU $5 \times$ F 1861 & 132.17 & $8.35^{* *}$ & $7.95^{* *}$ & 4.27 & 9.69 & 2.80 & 24.00 & -2.24 & -4.13 & 4.27 & 4.15 & 8.83 \\
\hline MCU 5 x SOCC 11 & 131.23 & $8.23^{* *}$ & 7.98 ** & 4.05 & 7.63 & 4.54 & 25.03 & 3.73 & 3.44 & 4.05 & 3.18 & -3.34 \\
\hline MCU $5 \times$ SOCC 17 & 137.67 & $17.08^{* *}$ & $13.27^{\star \star}$ & 4.06 & 12.63 * & 1.20 & 24.13 & -1.23 & -2.69 & 4.06 & 0.04 & -3.18 \\
\hline MCU $5 \times$ TCH 1641 & 143.07 & 17.93 ** & $17.72 * *$ & 4.06 & 6.24 & -2.27 & 23.07 & -0.07 & -4.16 & 4.06 & 0.33 & -3.18 \\
\hline MCU $5 \times$ TCH 1644 & 122.13 & 0.56 & 0.49 & 4.03 & 3.33 & 1.60 & 24.63 & 7.96 & 2.35 & 4.03 & 6.71 & -3.82 \\
\hline MCU 5 x TCH 1646 & 137.14 & 12.43 ** & $12.00 * *$ & 4.24 & 7.87 & 1.60 & 22.87 & -1.29 & -4.99 & 4.24 & 5.52 & 7.19 \\
\hline MCU 12 x F 776 & 129.20 & $6.87^{* *}$ & $6.45^{* *}$ & 4.35 & 17.00 ** & 6.49 & 24.33 & 7.51 & -3.31 & 4.35 & 6.62 & 5.08 \\
\hline MCU 12 x F 1861 & 122.07 & 0.52 & -0.30 & 4.03 & 0.80 & -4.01 & 32.37 & $28.95^{* *}$ & $28.61^{* *}$ & 4.03 & 7.90 & 6.50 \\
\hline MCU 12 x SOCC 11 & 123.73 & 0.86 & 0.63 & 4.36 & 4.06 & 2.76 & 29.40 & $19.11^{* *}$ & $16.82^{* *}$ & 4.36 & 11.76 * & 5.32 \\
\hline MCU $12 \times$ SOCC 17 & 121.63 & 3.93 * & 1.00 & 4.10 & $21.27^{* *}$ & 10.64 & 32.27 & $29.15^{* *}$ & $28.21 * *$ & 4.10 & 1.70 & -0.97 \\
\hline MCU 12 x TCH 1641 & 121.20 & 0.36 & 0.08 & 4.15 & $16.63^{* *}$ & 8.98 & 24.23 & 2.54 & -3.71 & 4.15 & 3.24 & 0.24 \\
\hline MCU 12 x TCH 1644 & 122.50 & 1.32 & 0.93 & 4.14 & 8.01 & 8.01 & 26.73 & $14.41 *$ & 6.23 & 4.14 & 10.49 * & 0.16 \\
\hline MCU $12 \times$ TCH 1646 & 122.20 & 0.62 & -0.22 & 4.31 & 9.38 & 4.70 & 26.13 & 10.19 & 3.84 & 4.31 & 7.89 & 4.11 \\
\hline SURABHI x F 776 & 127.73 & $5.13^{* *}$ & 5.02 ** & 4.21 & $23.88^{* *}$ & 12.69 * & 25.47 & 9.38 & -3.78 & 4.21 & 5.60 & 4.81 \\
\hline SURABHI x F 1861 & 133.07 & 9.04 ** & 8.68 ** & 4.27 & $14.78^{* *}$ & 9.24 & 25.13 & -2.39 & -5.04 & 4.27 & 7.29 & 6.66 \\
\hline SURABHI x SOCC 11 & 126.03 & 3.90 ** & $3.62 *$ & 3.82 & 2.31 & 0.97 & 24.43 & -3.55 & -7.68 & 3.82 & 0.39 & -3.37 \\
\hline SURABHI x SOCC 17 & 135.30 & 15.02 ** & 11.24 ** & 4.15 & 14.98 ** & 4.83 & 25.93 & 1.17 & -2.02 & 4.15 & 5.29 & 4.80 \\
\hline SURABHI x TCH 1641 & 121.37 & $6.59 * *$ & 6.36 ** & 3.89 & 13.29 * & 5.79 & 26.37 & 8.58 & -0.38 & 3.89 & -0.85 & -1.60 \\
\hline SURABHI x TCH 1644 & 125.83 & $3.57^{*}$ & $3.45 *$ & 3.97 & 9.18 & 9.10 & 24.90 & 3.68 & -5.92 & 3.97 & 8.56 & 0.42 \\
\hline SURABHI x TCH 1646 & 132.23 & $8.34^{* *}$ & $7.97^{* *}$ & 4.34 & 10.89 * & 6.07 & 25.40 & 4.24 & -4.03 & 4.34 & 11.23 * & 9.69 \\
\hline SVPR 2 x F 776 & 134.27 & 10.86 ** & $10.63 * *$ & 4.20 & 27.09 ** & $26.25 * \star$ & 24.57 & 11.84 & 3.08 & 4.20 & 3.28 & 1.94 \\
\hline SVPR 2 x F 1861 & 127.67 & $4.95^{* *}$ & $4.27^{*}$ & 4.17 & 15.83 ** & 11.15 & 25.50 & 4.37 & 1.86 & 4.17 & 2.71 & 1.21 \\
\hline SVPR $2 \times$ SOCC 11 & 128.77 & $6.49^{* *}$ & $6.45^{* *}$ & 4.20 & 12.08 * & 3.82 & 21.40 & -10.90 & -11.57 & 4.20 & 7.84 & 1.78 \\
\hline SVPR 2 x SOCC 17 & 129.00 & 10.02 ** & $6.73 * *$ & 4.14 & 22.60 ** & $22.09 * *$ & 23.97 & -1.44 & -3.36 & 4.14 & 3.03 & 0.49 \\
\hline SVPR $2 \times$ TCH 1641 & 121.41 & 0.37 & 0.28 & 4.12 & 5.61 & 3.34 & 24.40 & 6.24 & 2.38 & 4.12 & 2.74 & -0.08 \\
\hline SVPR $2 \times$ TCH 1644 & 133.00 & $9.81^{* *}$ & 9.59 ** & 4.21 & 1.21 & -7.32 & 24.43 & 7.64 & 2.52 & 4.21 & $12.47^{*}$ & 2.10 \\
\hline SVPR $2 \times$ TCH 1646 & 130.40 & $7.18^{* *}$ & $6.48^{* *}$ & 4.23 & 9.18 & 4.23 & 23.90 & 3.69 & 0.28 & 4.23 & 6.15 & 2.59 \\
\hline
\end{tabular}

*, Significant at $5 \%$ level; **, significant at $1 \%$ level; di, relative heterosis; dii, heterobeltiosis.

and $\mathrm{TCH} 1644$, respectively. In hybrids, it varied from 17.05 (MCU $12 \times \mathrm{TCH} 1641$ ) to $22.9 \%$ (Surabhi $x$ TCH 1646). The mean was 19.95 for hybrids. Pandey (1977) reported that the variability for oil content in improved strains of $G$. hirsutum ranged from 14.5 to $22.0 \%$ with mean of
19.2\% (Table 5). The earlier workers, Dani (1989), Dani (1991), Gotmare et al. (2004), Khan et al., (2007a) and Sharma et al., (2009) also reported 
Table 5. Mean performance and expression of heterosis in hybrids (\%) for Seed cotton yield, seed oil and protein content.

\begin{tabular}{|c|c|c|c|c|c|c|c|c|c|}
\hline \multirow{2}{*}{ Hybrid } & \multicolumn{3}{|c|}{ Seed cotton yield/plant (g) } & \multicolumn{3}{|c|}{ Seed oil (\%) } & \multicolumn{3}{|c|}{ Seed protein (\%) } \\
\hline & Mean & di & dii & Mean & di & dii & Mean & di & dii \\
\hline MCU 5 x F 776 & 99.71 & $20.40^{* *}$ & $14.70^{* *}$ & 19.17 & -0.77 & -1.00 & 28.70 & $17.00 * *$ & 3.65 \\
\hline MCU 5 x F 1861 & 116.13 & $32.93^{* *}$ & $32.27^{\text {**}}$ & 20.82 & $12.51^{* *}$ & $8.04^{* *}$ & 27.29 & 0.05 & -1.43 \\
\hline MCU $5 \times$ SOCC 11 & 104.63 & 27.39 ** & $20.36^{* *}$ & 21.26 & $10.25^{* *}$ & $10.17^{* *}$ & 27.09 & 0.18 & -2.17 \\
\hline MCU $5 \times$ SOCC 17 & 110.25 & 32.06 ** & $26.82^{* *}$ & 19.26 & -4.27 * & $-8.15^{* *}$ & 31.71 & 29.76 ** & 14.52 ** \\
\hline MCU 5 x TCH 1641 & 97.73 & $17.47^{* *}$ & $12.42^{* *}$ & 20.68 & -0.67 & $-7.55^{* *}$ & 29.08 & $19.89^{* *}$ & 5.03 \\
\hline MCU $5 \times$ TCH 1644 & 105.90 & 44.74 ** & $21.82^{* *}$ & 20.89 & 5.21 ** & 2.20 & 21.67 & -16.56 ** & $-21.75^{* *}$ \\
\hline MCU $5 \times$ TCH 1646 & 103.80 & $15.01 * *$ & 10.94 * & 18.89 & -3.88 * & -5.72 * & 27.44 & 7.08 ** & -0.90 \\
\hline MCU 12 x F 776 & 112.77 & $29.59 * *$ & 18.29 ** & 21.66 & 7.24 ** & 2.96 & 27.58 & $20.81^{* *}$ & 13.54 ** \\
\hline MCU 12 x F 1861 & 145.41 & $58.80 * *$ & $52.52^{* *}$ & 18.20 & $-6.14^{* *}$ & $-13.50 * *$ & 26.04 & 1.80 & -3.09 \\
\hline MCU $12 \times$ SOCC 11 & 137.03 & $58.73^{* *}$ & $43.74^{* *}$ & 20.01 & -0.77 & -4.88 * & 18.90 & $-25.41 * *$ & -28.38 ** \\
\hline MCU $12 \times$ SOCC 17 & 141.47 & $61.34^{* *}$ & 48.39 ** & 21.52 & 2.47 & 2.30 & 18.45 & $-18.86 * *$ & $-24.04 * *$ \\
\hline MCU 12 x TCH 1641 & 101.73 & $16.40^{* *}$ & 6.71 & 17.01 & $-21.63^{* *}$ & -23.96 ** & 25.10 & $11.27^{* *}$ & 3.33 \\
\hline MCU 12 x TCH 1644 & 114.87 & $48.47^{* *}$ & 20.49 ** & 20.51 & -1.13 & -2.53 & 25.80 & 6.32 * & 6.22 * \\
\hline MCU $12 \times$ TCH 1646 & 115.50 & 22.29 ** & $21.15^{* *}$ & 18.17 & -11.53 ** & -13.64 ** & 22.54 & $-5.80 *$ & -7.20 * \\
\hline SURABHI x F 776 & 102.60 & $23.00 * *$ & $16.41^{\star \star}$ & 21.86 & $13.15^{* *}$ & $17 . .93$ ** & 23.27 & $14.18^{* *}$ & 8.89 * \\
\hline SURABHI x F 1861 & 104.70 & 19.02 ** & $18.79^{* *}$ & 22.30 & $20.46^{* *}$ & 15.64 ** & 25.58 & 10.59 ** & -4.80 \\
\hline SURABHI x SOCC 11 & 94.40 & $14.10^{* *}$ & 7.11 & 18.99 & -1.56 & -1.59 & 24.99 & $9.17^{* *}$ & -5.31 \\
\hline SURABHI x SOCC 17 & 107.37 & 27.69 ** & $21.82^{* *}$ & 19.02 & $-5.48^{* *}$ & $-9.28^{* *}$ & 27.47 & 35.40 ** & $29.66^{* *}$ \\
\hline SURABHI x TCH 1641 & 102.30 & 22.08 ** & $16.07^{* *}$ & 20.30 & -2.51 & $-9.24^{* *}$ & 22.92 & 13.98 ** & $10.05^{* *}$ \\
\hline SURABHI x TCH 1644 & 92.79 & 25.78 ** & 5.28 & 18.91 & $-4.77 *$ & $-7.47^{* *}$ & 19.18 & -12.09 ** & $-20.89 * *$ \\
\hline SURABHI x TCH 1646 & 87.70 & -3.47 & -6.27 & 22.90 & $15.46^{* *}$ & 13.29 ** & 14.18 & $-33.99 * *$ & $-39.84 * *$ \\
\hline SVPR 2 x F 776 & 99.63 & 17.40 ** & 9.45 * & 19.64 & 1.05 & 0.67 & 14.35 & -37.52 ** & -41.58 ** \\
\hline SVPR 2 x F 1861 & 108.00 & 20.78 ** & $18.64^{* *}$ & 16.63 & -10.71 ** & -14.76 ** & 14.33 & $-44.26 * *$ & -46.66 ** \\
\hline SVPR $2 \times$ SOCC 11 & 94.47 & 12.22 ** & 3.77 & 20.86 & 7.51 ** & 6.92 ** & 14.85 & -41.71 ** & $-43.73^{* *}$ \\
\hline SVPR $2 \times$ SOCC 17 & 100.29 & 17.26 ** & $10.17^{*}$ & 19.44 & -3.95 * & -7.30 ** & 21.31 & -6.84 * & -13.24 ** \\
\hline SVPR 2 x TCH 1641 & 97.83 & $14.76^{\star *}$ & 7.47 & 20.13 & $-3.87 *$ & $-10.01^{* *}$ & 16.59 & $-26.89 * *$ & $-32.45^{* *}$ \\
\hline SVPR 2 x TCH 1644 & 97.10 & 29.09 ** & 6.66 & 17.99 & -9.94 ** & $-11.99 * *$ & 14.21 & $-41.77^{\star *}$ & -42.15 ** \\
\hline SVPR $2 \times$ TCH 1646 & 98.70 & 6.93 & 5.49 & 18.62 & $-5.85 * *$ & $-7.09 * *$ & 14.98 & $-37.75^{\star *}$ & $-39.01 * *$ \\
\hline
\end{tabular}

${ }^{*}$, Significant at $5 \%$ level; ${ }^{* *}$, significant at $1 \%$ level; di, relative heterosis; dii, heterobeltiosis.

similar findings, and supported our results. Hassan et al. (2005) studies exhibited the performance of Egyptian cotton cultivars for cottonseed oil percentage and found significant mean differences. Soomro et al. (2008) observed cottonseed oil percentage ranged from 27.52 to $30.15 \%$ among eight upland cotton cultivars and it was negatively correlated with seed cotton yield.

The protein content in parents ranged from $19.4 \%$ in Surabhi to $27.7 \%$ in MCU 5 . In hybrids, it varied between $14.18 \%$ (Surabhi $\times$ TCH 1646) and $31.71 \%$ (MCU $5 \times$ SOCC17), and mean was $22.34 \%$ for hybrids. A mean protein content of $32.7 \%$ was noticed among the 300 accessions analysed by Liu et al. (1994) in Gossypium barbadense which support the present study.

\section{Expression of heterosis for yield attributing traits}

The relative heterosis for plant height ranged from 3.6 in Surabhi $x$ TCH 1644 to 17.9 in MCU $5 \times$ TCH 1641 over mid parental value in positive direction (Table 4). Out of
27 hybrids, significant positive heterobeltiosis was observed in 19 hybrids, the range being 3.5 (Surabhi $x \mathrm{TCH}$ 1644) to 17.7 (MCU $5 \times \mathrm{TCH} 1641$ ). These results find support from those of Sayal et al. (1999), Hassan et al. (1999) and Rauf et al., (2005) who observed considerable amount of heterosis for plant height. For number of sympodia, significant relative heterosis percent manifested the hybrids varied from, 10.89 in Surabhi $\times$ TCH 1646 to 27.09 in SVPR $2 \times \mathrm{F} 776$ over mid parental value in positive direction. The heterobeltiosis effect was significant in positive direction in SVPR 2 x F 776 (26.25 per cent), SVPR 2 x SOCC 17 (22.09 per cent) and Surabhi $x$ F 776 (12.69 per cent). Heterosis values were significantly positive in 16 cross combinations for relative heterosis and 15 hybrids were recorded significantly positive values over better parent. This is similar with earlier finding of Koodalingam et al. (1991) and Ganapathy and Nadarajan (2008). The hybrid MCU 12 x SOCC 17 recorded highest relative heterosis $(29.15 \%)$ and heterobeltiosis $(28.21 \%)$ whereas, the lowestrelative heterosis $(12.75 \%)$ 
and heterobeltiosis (16.82\%) were observed in the hybrid MCU 5 x F 776, and MCU 12 x SOCC 11, respectively. Ganapahty and Nadarajan, (2008), reported for number of bolls per plant, the highest relative heterosis $(62.24 \%)$ and heterobeltiosis (53.19\%) in the same hybrid CWROK $165 \times$ MCU 7. This report also confirmed our results. Among 28 hybrids, four hybrids expressed significantly positive relative heterosis and three hybrids showed significantly positive heterosis values over better parent for number of bolls per plant (Table 4). Heterosis for boll weight significantly ranged from MCU $12 \times \mathrm{TCH} 1644$ (10.29\%) to SVPR $2 \times \mathrm{TCH} 1644(12.47 \%)$, and four hybrids were significantly positive for relative heterosis. None of the hybrids had shown significant heterobeltiosis in the positive direction. Heterosis for number of seeds per boll ranged from -8.55 to $14.81 \%$ for relative heterosis and 11 hybrids for positive heterobeltiosis were observed (Ganapathy and Nadarajan, 2008). In this study, nineteen hybrids recorded significant relative heterosis ranging from $7.31 \%$ in MCU $5 \times \mathrm{TCH} 1644$ to $22.95 \%$ in SVPR $2 \times$ SOCC 11 and five hybrids registered significant positive heterobeltiosis for number of seeds per boll.

The heterotic expression of relative heterosis for ginning outturn was significant and positive in nine hybrids. Heterobeltiotic effect was positive in three hybrids. The highest positive relative heterosis (18.29\%) and heterobeltiosis $(11.48 \%)$ were observed in same hybrid SVPR $2 \times$ SOCC 17. Earlier researcher (Rauf et al., 2005) reported two $F_{1}$ hybrids that had 12.64 and $22.95 \%$ for ginning outturn relative heterosis and heterobeltiosis. Also, these results are in accordance with those of Zhang et al. (1994) and Soomro (2000). Relative heterosis effect for lint index was positive in two hybrids, and none of the hybrids were found to be significant over the parent (Table 4). For seed index, relative heterosis values was positive and significant in MCU $5 \times \mathrm{TCH} 1646$ (27.17\%) and SVPR $2 \times$ TCH 1646 (21.20\%). Significant positive heterobeltiosis values were registered by two hybrids MCU $5 \times$ TCH 1646 and SVPR $2 \times$ TCH 1646 recorded 19.33 and $21.00 \%$, respectively. Virk and Kalsy (1982), Khan (1986), and Rahman et al. (1993) also reported positive heterosis as well as heterobeltiosis for seed index.

\section{Expression heterosis for seed cotton yield}

For seed cotton yield, 26 hybrids displayed significant positive heterosis over mid parental value with a range of $12.22 \%$ in SVPR 2 x SOCC 11 to $61.34 \%$ in MCU $12 \mathrm{x}$ SOCC 17. Significant positive heterobeltiotic effect over better parent was observed in 20 hybrids for seed cotton yield. Ganapathy and Nadarajan (2008) also reported positive heterobeltiotic effect over better parent 20 hybrids for seed cotton yield. Similar results were already reported by Chaudhari et al. (1992) for seed cotton yield. Among them, hybrid MCU 12 x F 1861(52.52\%) registered highest positive heterobeltiosis over better parent value with highest per se performance of $145.41 \mathrm{~g} /$ plant.
This same hybrid also expressed significant positive heterosis for number of bolls per plant, boll weight and lint index. The hybrid MCU $12 \times \mathrm{F} 1861$ is the best combination in the present study, for direct exploitation. The results suggested that high yield does not necessarily depend on high heterotic expression for all the yield components and high heterosis for some or few of component traits, which are ultimately associated with yield, can generate significant yield heterosis (Kapoor et al., 2002).

\section{Expression of heterosis for seed oil and protein content}

Eight hybrids exhibited significant positive relative heterosis over mid parent, and among them Surabhi x F 1861 $(20.46 \%)$ exhibited highest relative heterosis over mid parent. Six hybrids exhibited significant positive heterobeltiosis for seed oil content. Of these, hybrid SVPR $2 \times$ SOCC 11 (15.64\%) exhibited the highest hetero-beltiosis (Table 5). Ganapathy and Nadarajan (2008) reported 19 hybrids had positive heterosis over mid parent and 14 hybrids over better parent for seed oil content and these results confirmed our studies. Similar results were also reported by earlier researchers (Dani, 1988; Kapoor et al., 1994; Kowsalya et al., 1999) in cotton. The hybrid Surabhi $\times$ TCH 1646 exhibited highest sca effects 2.36 with highest mean performance $22.90 \%$ of seed oil content. The same hybrid also exhibited positive heterosis over mid parent up to the extent of $15.46 \%$ and over better parent with a value of $13.29 \%$. This hybrid is the best combination in the present study for direct seed oil content exploitation. Positive heterosis for cotton seed oil content was already reported by earlier workers (Kashalkar et al., 1989; Kowsalya et al., 1999; Manimaran and Raveendran, 2004; Ganapathy and Nadarajan, 2008).

Twelve (12) hybrids exhibited positive significant relative heterosis over mid parent for seed protein content (Table 5). Among these, hybrid Surabhi X SOCC 17 exhibited highest relative heterosis $(35.40 \%)$ over mid parent. The same hybrid Surabhi X SOCC 17 also exhibited highest heterobeltiotic effect $(29.66 \%)$. Kowsalya et al. (1999) reported positive heterotic expression over mid and better parent for seed protein content in cotton and it is supported our results.

\section{Conclusion}

Cottonseed oil is edible oil extracted from the seeds of cotton plant of several species, primarily G. hirsutum and Gossypium herbaceum. Cotton seed meal is used principally as a protein concentrate feed for livestock. Presently, human population growth is rapidly increasing throughout the world, and this condition, we need to fulfill the consumer edible oil requirement. Nowadays, cotton crop is primarily cultivated for fibre production in most of the countries worldwide. In addition, cotton seed also had the sufficient amount of oil and protein content. There- 
fore, the present studies were made to improve seed oil content along with higher seed cotton yield by Line $x$ Tester analysis. The present study results show that $F_{1}$ hybrid mean values were higher than for parents for all the 11 traits. In addition, the hybrid MCU $12 \times$ SOCC 17 exhibited higher per se performance and heterotic effect for seed cotton yield along with seed oil content, and MCU $5 \times$ SOCC 17 recorded more seed protein combined with seed cotton yield. Surabhi x TCH 1646 exhibiting highest per se performance and heterotic effect for seed oil content was found to be best for directional selection. The highest heterosis was observed for seed cotton yield and cottonseed oil followed by other traits. An increase in cottonseed oil, seed protein, seed cotton yield and other traits will be a valuable addition to cotton cultivars.

\section{REFERENCES}

Ansari BA, Mari S, Rajper AA (2006). Heterosis in diallel crosses of spring wheat under two fertility regimes. Ind. J. Plant Sci. 5(1): 722727.

Ansari BA, Mari SN, Rajper AA (2005). Assessment of significant heterosis in diallel hybrids for spike length in spring wheat under two fertility regimes. Ind. J. Plant Sci. 4(1):51-56.

Ansari KA, Ansari BA, Khund A (2004). Extent of heterosis and heritability in some quantitative characters of bread wheat. Ind. J. Plant Sci. 3(2): 189-192.

Anwar AM, Gill MI, Muhammad D, Afzal MN (2002). Evaluation of cotton varieties at different doses of nitrogen fertilizer. Pak. Cottons 46(1-4): 35-41.

Baloch MJ (2002). Relative performance of F1 and F2 inter hirsutum hybrids for some quantitative traits in upland cotton. Pak. J. Sci. Ind. Res. 45(6): 407-411.

Baloch MJ (2004). Genetic variability and heritability estimates of some polygenic traits in upland cotton. Pak. J. Sci. Ind. Res. 42(6): 451454.

Baloch MZ, Ansari BA, Memon N (2003). Performance and selection of intraspecific hybrids of spring wheat (Triticum aestivum L.). Pak. J. Agric. Agril. Engg. Vet. Sci. 19(1): 28-31.

Basbag S, Gencer O (2004). Investigations on the heritability of the cotton seed yield components and technological characters in cotton (G. hirsutum). Pak. J. Sci. 7: 1390-1393.

Chandio MA, Kalwar MS, Baloch GM (2002). Gene action for some quantitative characters in upland cotton (G. hirsutum). Pak. J. Sci. Res. 54(1-2): 31-35.

Chaudhari PN, Borole DN, Tendulkar AV, Narkhede BN (1992). Heterosis for economic traits in intra-specific crosses of desi cotton. J. Maharashtra Agric. Univ. 17(2): 273-276.

Copur O (2006). Determination of yield and yield components of some cotton cultivars in semi-arid conditions. Pak. J Biol. Sci. 9(14) 25722578.

Dani RG (1988). Heterosis for oil content in cotton. Ann. Agric. Res. 9(1): 135-136.

Dani RG (1989). Heterosis and combining ability for oil content and other economic traits inupland cotton (G. hirsutum). Indian J. Genet. 209: 209-212.

Dani RG, Kohel RJ (1989). Maternal effect and generation mean analysis of seed oil content in cotton (G. hirsutum). Theor. Appl. Genet. 77: 569-575.

Dani, RG (1991). Analysis of combining ability for seed oil content in cotton (G. hirsutum). Acta Agron. Hungarica 40: 123-127.

Ehsan F, Nadeem A, Tahir MA, Majeed A (2008). Comparitive yield performance of new cultivars of cotton (Gossypium hirsutum L.). Pak. J. Life Soc. Sci. 6 (1):1-3.

Fehr WR (1987). Principles of cultivar development. Theory and technique. Macmillan Pub. Co. Inc. New York. pp.115-119.
Ganapathy S, Nadarajan N (2008). Heterosis studies for oil content, seed cotton yield and other economic traits in cotton (G. hirsutum L.). Madras Agric. J. 95 (7-12):306-310.

Gite VK, Misal MB, Kalpande (2006). Correlation and path analysis in cotton (Gossypium hirsutum L.) J. Cotton Res. Dev. 20:51-54.

Gotmare V, Singh P, Mayee D, Deshpande V, Bhagat C (2004). Genetic variability for seed oil and seed index in some wild species and perennial races of cotton. Plant Breed. 123: 207-208.

Hassan G, Mahmood G, Khan N, Razzaq A (1999). Combining ability and heterobeltiosis estimates in diallel cross of cotton (Gossypium hirsutum L.) Sarhad. J. Agric. 15: 563-568.

Hassan ISM, Mohamed AS, Abdel-Rahman LMA (2005).Comparative study on seed cotton yield, oil and protein contents in the seed of some Egyptian cotton cultivars grown atdifferent locations. Egyptian J. Agric. Res., 83: 735-750.

Hofs JL, Hau B, Marais D (2006). Boll distribution patterns in Bt and non-Bt cotton cultivars: I. Study on commercial irrigated farming systems in South Africa. Field Crops Res. 98(2 \& 3): 203-209.

Humphries EC (1956). Mineral components and ash analysis. In: Modern methods of plant analysis. Springes-verlag, Berlin. pp. 468502.

Kapoor CJ, Bhardwaj RP, Mathur GM (1994). Heterosis for oil content in upland cotton. Indian Soc. Oil seeds Res. 109-110.

Kempthorne O (1957). An introduction to genetic statistics. John Wiley and Sons, $1^{\text {st }}$ edition, New York, USA. pp. 456-471.

Khan MA (1986). Heterotic and heterobeltiotic studies for quality traits in intraspecific crosses of upland cotton. Sarhad J. Agric. 1: 137-144.

Khan N, Basal H, Hassan G (2010). Cottonseed oil and yield assessment via economic heterosis and heritability in intraspecific cotton populations. Afr. J. Biotechnol. 9(44), 7418-7428.

Khan NU, Hassan G, Kumbhar MB, Kang S, Khan I, Parveen A, Aiman $U$, Saeed M (2007a). Heterosis and inbreeding depression and mean performance in segregating generations in upland cotton. Eur. J. Sci. Res. 17: 531-546.

Khan NU, Hassan G, Kumbhar MB, Parveen A, Aiman U, Ahmad W,Shah SA, Ahmad S (2007b). Gene action of seed traits and its oil content in upland cotton (G. hirsutum). Sabrao J. Breed. Genet. 39:17-30.

Kohel RJ (1980). Genetic studies of seed oil in cotton. Crop Sci. 20: 684-686.

Koodalingam K, Rajasekaran S, Ramalingam A (1991). Heterosis and inbreeding depression in inter-specific upland cotton. Ann. Agric.Res. 12 : 288-291.

Kowsalya R, Raveendran TS, Pushpalatha T (1999). Heterosis and inbreeding depression for seed oil and protein contents in upland cotton (G. hirsutum L.). Madras Agric. J. 86: 362-365.

Liu M, Fan JH, You BC, Mei YJ (1994). Protein and oil contents in the seed of $G$. barbadense L. Crop Gene Res. 4: 25-28.

Manimaran R, Raveendran TS (2004). Estimation of genetic parameters in cotton genotypes. Agric. Sci. Digest 24 (3): $209-211$

Memon S, Ansari BA, Memon A (2005). Estimation of heterosis and interrelationship between important agro-economic traits of bread wheat. Ind. J. Plant Sci. 4(3): 355-361.

Pandey SN (1977). Utilization of cotton seed and its products. Cotton Dev. 7(1): 4-9.

Preetha S, Raveendran TS (2007). Genetic variability and association analysis in three different morphological groups of cotton (G. hirsutm L.). Asian J. Plant Sci. 6: 122-128.

Rahman S, Khan MA, Ayub M, Khan MA (1993). Heterosis and heterobeltiosis for lint percentage, seed and lint indices and stable length in different cross combination of five cotton cultivars. Pakistan J. Agric. Res. 14 (2\&3): 115-120.

Rauf S, Khan TM, Nazir S (2005). Combining ability and heterosis in ( $G$ hirsutum L.) Int. J. Agri. Biol. 7 (1): 109-113.

Rauf S, Khan TM, Sadaqat HA, Khan Al (2004). Correlation and path coefficient analysis of yield components in cotton (Gossypiumhirsutum L.). Int. J. Agric. Biol. 6: 686-688

Sayal AU, Baloch MS, Hussain I, Khan B (1999). Exploration of heterosis and heterobeltiosis in American Cotton (Gossypium hirsutum L.) J. Agric. Res. 37: 201-208.

Sharma D, Pathak D, Atwal AK, Sangha MK (2009). Genetic variation for some chemical and biochemical characteristics in cotton seed oil. 
J. Cotton Res. Dev. 23 (1): 1-7.

Soomro AR (2000). Assessment of useful heterosis in glandless Gossypium hirsutum cotton strains through their performance in hybrid combination. Pak. J. Bot. 32: 65-68.

Soomro ZA, Larik AS, Khan NU, Baloch MJ, Mari S, Memon S, Panhwar NA (2008). Genetic variability studies on quantitative traits in upland cotton. Sarhad J. Agric. 24 (4): 587-592.

Virk PS, Kalsy HS (1982). Combining ability analysis for some quality traits in upland cotton (G. hirsutum L.). J. Crop Improve. 9 (2):152155.

Wei XC, Li QZ, Pang JQ, Zhang J, Zhao JH, Wang LG (2002). Heterosis of pre-forest lint yield of hybrid between cultivars or lines within upland cotton (G. hirsutum L.). Cotton Sci. 14: 269-272.

Williams W, Gilbert NE (1960). Heterosis and inheritance of yield in the tomato. Heredity 15: 133-150.
Yuan YL, Zhang TZ, Guo WZ, Pan JJ, Kohel RJ (2002). Heterosis and gene action of boll weight and lint percentage in high quality fibre property varieties in upland cotton. Acta Agron. Sin. 28: 196-202.

Zhang JF, Deng Z, Sun JZ, Liu JL (1994). Heterosis and combining ability in interspecific crosses between Gossypium hirsutum and G.barbadense. Acta. Agron. Sin. 13: 9-14.

Zhang ZS, Li XB, Liu DJ, Huang SL, Zhang FX (2002). Study on heterosis utilization of upland cotton ( $G$. hirsutum L.) lines with high fibre quality. Cotton Sci. 14: 264-268. 